\section{УДК: 613.95(477)+613.955(477)}

\section{О.В. Тяжка, Л.М. Казакова, М.М. Васюкова, А.М. Антошкіна}

Національний медичний університет ім. О.О.Богомольця (м.Київ, Україна)

Ключові слова: учнігімназії, показникиздоров'я, фізичний розвиток, індекс Руф'є.

\section{СТАН ЗДОРОВ'Я УЧНІВ СЕРЕДНЬОГО ШКІЛЬНОГО ВІКУ ОДНІЕЇ 3 ГІМНАЗІЙ М. КИЄВА}

Резюме. У зв'язку з розвитком мережі гімназій у Києві, підвищенням психоемоційного навантаження в учнів спеціалізованих шкіл нами було вивчено стан здоров'я, показники фізичного розвитку та адаптаційних можливостей сериево-судинної системи у 107 дітей 5-6 класів однієї з гімназій у м.Києві. Встановлено, що в структурі захворюваності у 97,2\% дітей переважали зміни кістково-м'язової системи (переважно поєднання патологіi): сколіоз та порушення постави - у 33,6\% і 36,4\% відповідно; плоскостопість - у 49\%, деформація грудної клітки і залишкові явища рахіту - y 24,5\%, патологія зводу стопи - у 49\%, порушення прикусу, карієс зубів - у 11,5\% дітей. Захворювання шлунково-кишкового тракту, переважно функиіонального характеру, мали 41,1\% дітей. Патологія ЛОР-органів і патологія зору відзначені у 33,7\% і 24,0\%, відповідно. При оцінці фізичного розвитку встановлено, щяо 70,7\% учнів гімназії мають середній, 13,3\% - вище середнього, високий i дуже високий рівень фізичного розвитку; при иььому дисгармонійний розвиток виявлено у 21,3\% дітей, у половини дітей з них - за рахунок ожиріння 1 ступеня.

Для розробки індивідуальних рекомендацій до фізичних навантажень оиінювали адаптаційні можливості сериево-судинної системи за індексом Руф'є. Тільки 10,6\% школярів-гімназистів мали високий $і$ вище середнього рівні фізичного здоров'я; у 21,4\% учнів показники були середніми (можливість відвідувати підготовчу групу). У більшості ж (68,0\%) дітей зареєстрований функиіональний резерв сериево-судинної системи нижче середнього, тобто згідно з наказом МОЗ України №518 / 674 вони можуть відвідувати лише спещіальну групу з фізкультури. Результати наших досліджень свідчать про низький рівень адаптаційних можливостей сериево-судинної системи, наявності поєднаної системної патології на тлі відносно задовільних показників фізичного розвитку, щяо вимагає розробки індивідуалізованих реабілітаційних та тренувальних програм учням гімназій для підвищення їх можливостей щзодо виконання навчального навантаження.

У зв'язку з розвитком мережі гімназій у Києві, підвищенням психоемоційного навантаження в учнів спеціалізованих шкіл, нами було вивчено стан здоров'я, показники фізичного розвитку та адаптаційних можливостей серцево-судинної системи у 107 дітей 5-6 класів однієї з гімназій в м.Києві. Встановлено, що у структурі захворюваності в 97,2\% дітей переважали зміни кістковом'язової системи (переважно поєднання патологіi): сколіоз та порушення постави - у $33,6 \%$ i $36,4 \%$ відповідно; плоскостопість - у 49\%, деформація грудної клітки і залишкові явища рахіту - у $24,5 \%$, патологія зводу стопи - у 49\%, порушення прикусу, карієс зубів - у 11,5\% дітей. Захворювання шлунково-кишкового тракту, переважно функціонального характеру, мали $41,1 \%$ дітей. Пато- логія ЛОР-органів і патологія зору відзначені у $33,7 \%$ і 24,0\%, відповідно.

При оцінці фізичного розвитку встановлено, що $70,7 \%$ учнів гімназії мають середній, $13,3 \%$ вище середнього, високий і дуже високий рівень фізичного розвитку; при цьому дисгармонійний розвиток виявлено у $21,3 \%$ дітей, у половини дітей 3 них - за рахунок ожиріння 1 ступеня.

Для розробки індивідуальних рекомендацій до фізичних навантажень оцінювали адаптаційні можливості серцево-судинної системи за індексом Руф'є. Тільки 10,6\% школярів-гімназистів мали високий і вище середнього рівні фізичного здоров'я; у $21,4 \%$ учнів вони були середніми (можливість відвідувати підготовчу групу). У більшості ж $(68,0 \%)$ дітей зареєстрований функці- 
ональний резерв серцево-судинної системи нижче середнього, тобто згідно з наказом МО3 України №518 / 674 вони можуть відвідувати лише спеціальну групу з фізкультури.

Результати наших досліджень свідчать про низький рівень адаптаційних можливостей серцевосудинної системи, наявність поєднаної системної патології на тлі відносно задовільних показників фізичного розвитку, що вимагає розробки індивідуалізованих реабілітаційних та тренувальних програм учням гімназій, для підвищення їх можливостей щодо виконання навчального навантаження.

Ключові слова: учні гімназії, показники здоров'я, фізичний розвиток, індекс Руф'є.

В останні роки в Україні значно поширилися мережі гімназій і ліцеїв. Узагальнення педагогічного досвіду свідчить про збільшення об'єму навчального навантаження, ускладнення навчальних програм з різних дисциплін в умовах гімназійної освіти в порівнянні із загальноосвітньою школою. Так, за даними авторів [13] більш ніж 40\% розроблених програм, підручників орієнтовані на підвищений рівень освіти, у той час як відсоток обдарованих дітей $є$ значно меншим i складає 6\%, а дітей, що мають високий рівень навчальних можливостей - лише 15\%. Перевантаженість школярів учбовим матеріалом коливається від трикратного (іноземна мова) до десятикратного (математика) перевищення можливостей дітей; час, що витрачається на підготовку домашніх завдань у загальноосвітній школі складає 7-8 годин, у гімназії - від 8,5 до 10 годин [12].

Дані літератури свідчать, що навантаження учнів інноваційних шкіл призводить до суттєвих порушень режиму дня і гігієнічних основ життєдіяльності дитини та $є$ чинником значних відхилень у фізичному здоров $і ̈$ [12].

Наразі стан здоров'я учнів гімназій в Україні вивчено недостатньо, а ті нечисленні дослідження що існують, стосуються здебільшого учнів молодших класів [13]. Тому метою нашого дослідження було вивчення стану здоров'я, фізичного розвитку та адаптаційних можливостей дітей середнього шкільного віку (5-6 клас).

Нами було обстежено 107 учнів однієї з гімназій Деснянського району загально прийнятими клінічними методами (оцінка стану здоров'я та фізичного розвитку) та адаптаційних можливостей до фізичного навантаження дітей за даними вивчення індексу Руф’є (IP), який дозволяє оцінити резерви серцево-судинної системи (показник рекомендований у Наказі № 518/674 від 20.07.09. MO3 України) та диференціювати 5 рівнів адаптаційних можливостей дитини у відповідь на певне фізичне навантаження (дитина робить 30 присідань протягом 40 с). Визначення індексу проводилося за відповідною формулою: IP $=[4 \times$ (ЧСС1+ЧСС2+ЧСС3) - 200] : 10, де ЧСС1 пульс за 15 сек. у стані спокою; ЧСС2 - пульс за перші 15 сек. першої хвилини відновлення після навантаження; ЧСС 3 - пульс за останні 15 сек. першої хвилини відновлення. Індекс оцінювали за наступними критеріями: менше 3 розцінюють як високий; 4-6 - вище середнього (добрий); 7-9 - середній; 10-14 нижче середнього (задовільний); більше 15 - низький (незадовільний) рівень адаптації.

Отримані дані клінічного обстеження свідчили про те, що в дітей переважали порушення кістково-м'язової системи $(97,2 \%)$, причому у більшості з них - поєднані. Найбільш частою патологією було ураження хребта (70,1\% учнів) у вигляді порушення постави та сколіозу I, II ступеня (відповідно 33,6\% і 36,4\%); патологія склепіння стопи (плоскостопість, клишоногість) виявлено у 49\% дітей, деформація грудної клітки (16,8\%), та залишкові явища рахіту $(7,7 \%)$, порушення росту зубів та аномалії прикусу $(19,2 \%)$, карієс - у 11,5\% учнів. Сучасні спеціалісти розцінюють стан опорно-рухового апарату як узагальнюючий показник здоров'я дитини у цілому, що зумовлено тим, що ця патологія має вплив на стан практично усіх систем та органів.

У обстежених дітей ураження шлунково-кишкового тракту також зустрічалось досить часто і було діагностовано у 41,1\% дітей; у більшості 3 них $(31,8 \%)$ захворювання мали функціональний характер (дисфункції біліарного тракту і функціональний закріп). Хронічні запальні захворювання травної системи (холецистит, гастродуоденіт) зареєстровані у 9,3\% дітей.

Відомо, що різні функціональні порушення органів і систем, у тому числі й вегетативні розлади, є не тільки факторами ризику формування соматичної патології, але в свою чергу впливають на фізичний та психічний розвиток дітей, особливо у дітей молодшого та середнього шкільного віку, коли фізіологічні зміни в дитячому організмі співпадають зі змінами соціальними. Це часто пов'язано із порушеннями адаптаційних реакцій організму дитини, з так званим синдромом «шкільної дизадаптації», яка є результатом взаємодії біологічних, психологічних та соціальних факторів $[6,7]$. Тому процес адаптації в цьому періоді розвитку дитини має характер стресової реакції. Довготривале перебування в таких умовах сприяє формуванню різноманітних вегетативних дисфункцій (ВД), що підтверджується даними літератури; в Україні погіршення здоров'я школярів супроводжується зростанням у них кількості функціональних розладів, зокрема вегетативних дисфункцій $[5,6]$. Дослідження В.Г.Майданника (2006) свідчать, що вегетативні дисфункції виявляються у $20 \%$ загальної популяції дітей, а з віком збільшуються і реєструються у 33\% дітей підліткового віку.

За нашими даними вегетативні розлади перебігали переважно у вигляді вегето-вісцеральних дисфункцій. Вони спостерігались більш ніж у 3/4 дітей з захворюваннями шлунково-кишкового тракту. Окрім вегето-вісцеральних дисфункцій у $12,1 \%$ випадків були діагностовані інші форми вегетатитивних дисфункцій - нейроциркулятирна 
та вегето-судинна, у тому числі за кардіальним типом. Таким чином, 43,9\% школярів мали ту чи іншу форму або одночасно дві форми порушення вегетативного гомеостазу, займаючи друге місце в структурі захворюваності дітей середнього шкільного віку $(46,7 \%)$. Спостерігались також поодинокі випадки дефектів мовлення.

Приблизно кожна третя дитина мала патологію ЛОР-органів (33,7\% випадків): у 29,9\% обстежених спостерігався хронічний тонзиліт (у тому числі, у сполученні з аденоїдитом); у 2,7\% учнів було діагностовано гіпертрофію піднебінних та носоглоткової мигдаликів без ознак хронічного запалення, скривлення носової перетинки, хронічний синусит.
При дослідженні серцево-судинної системи за клініко-анамнестичними даними у 12 дітей були виявлені зміни у вигляді пролапсу мітрального клапану або додаткових хорд лівого шлуночка.

У чверті дітей відмічалась патологія зору, частіше міопія, дещо рідше - гиперметропія, астигматизм. Порушення обміну спостерігались у кожної десятої дитини, в тому числі у вигляді ожиріння переважно I ступеня. За даними медичних карт алергічні захворювання відмічались у 6,7\% обстежених учнів (атопічний дерматит), але на момент обстеження вони не мали клінічних проявів загострення. Інформація, щодо захворюваності обстежених школярів наведена в табл. 1 .

Таблиця 1

Показники захворюваності школярів гімназії

\begin{tabular}{|c|c|c|}
\hline Найменування класів хвороб & \begin{tabular}{|c|} 
Всього дітей гімназії \\
$(n=107)$
\end{tabular} & $\begin{array}{c}\text { Всього дітей гімназії } \\
(100 \%)\end{array}$ \\
\hline Хвороби кістково-м'язової системи & 104 & 97,2 \\
\hline Порушення постави & 36 & 33,6 \\
\hline Сколіоз, кіфоз & 39 & 36,4 \\
\hline Всього хвороби хребта & 75 & 70,1 \\
\hline Дефрормація грудної клітки & 18 & 16,8 \\
\hline Кили (пупкова, пахвинна) & 5 & 4,8 \\
\hline Kapiєc & 12 & 11,5 \\
\hline Порушення росту зубів, аномалії прикусу & 20 & 19,2 \\
\hline Залишкові явища рахіту & 8 & 7,7 \\
\hline Плоскостопість, клишоногість & 51 & 49 \\
\hline Хвороби серцево-судинної системи & 12 & 11,5 \\
\hline Хвороби нервової системи & 50 & 46,7 \\
\hline Вегетативні дисфункції & 47 & 43,9 \\
\hline Дислалія & 3 & 2,8 \\
\hline Хвороби органів зору & 25 & 24 \\
\hline Патологія нирок & 5 & 4,8 \\
\hline Хвороби органів травлення & 44 & 41,1 \\
\hline Функціональні & 34 & 31,8 \\
\hline Хронічні, органічні & 10 & 9,3 \\
\hline Хвороби ЛОР органів & 35 & 33,7 \\
\hline Гіпертрофія мигдаликів & 1 & 0,9 \\
\hline Хронічний аденотонзиліт & 32 & 29,9 \\
\hline Скривлення носової перетинки & 1 & 0,9 \\
\hline Хронічний синусит & 1 & 0,9 \\
\hline Алергічні хвороби & 7 & 6,7 \\
\hline Хвороби ендокринної системи, розлади живлення & 11 & 10,6 \\
\hline Ожиріння & 10 & 9,3 \\
\hline Гіпотрофія & 1 & 0,9 \\
\hline Туб. інфрікування & 6 & 5,8 \\
\hline Інші хвороби та аномалії розвитку & 2 & 1,9 \\
\hline
\end{tabular}

Враховуючи те, що фізичний розвиток $є$ інтегральною характеристикою здоров'я дитини, ми визначали фізичний розвиток школярів. Було встановлено, що майже 70,7\% учнів гімназії мають середній, 13,3\% - вище середнього рівні фізичного розвитку. Звертає увагу той факт, що 1/6 частина учнів були «високорослими» - мали високий і дуже високий рівень фізичного розвитку. Лише у 5,3\% дітей фізичний розвиток був нижче за середній. Гармонійний (відповідність маси тіла до росту) фізичний розвиток відмічався у 78,7\% учнів; у 21,3\% дітей фізичний розвиток був дисгармонійним, в половині випадків за рахунок ожиріння переважно 1 ступеня. Дані щодо фізичного розвитку обстежених школярів наведені в табл. 2.

За даними Неделько В.П., Камінскої Т.М., Руденко С.А. та ін. [1] при вивченні адаптаційних можливостей дітей шкільного віку м. Києва встановлено, що більш ніж у $20 \%$ вони були незадовільними, а у $60 \%$ виявлено напружену адаптацію 
Таблиця 2

Стан фізичного розвитку школярів гімназії середнього віку

\begin{tabular}{|l|c|c|}
\hline \multicolumn{1}{|c|}{ Оцінка } & Всього дітей гімназії Абс. & Всього дітей гімназії \% \\
\hline Кількість дітей & 75 & 100 \\
\hline Дуже високий & 2 & 2,7 \\
\hline Високий & 6 & 13,0 \\
\hline Вище середнього & 10 & 70,7 \\
\hline Середній & 53 & 4,0 \\
\hline Нижче середнього & 3 & - \\
\hline Низький & - & 1,3 \\
\hline Дуже низький & 1 & 21,3 \\
\hline $\begin{array}{l}\text { Дисгармонійність фрізичного роз- } \\
\text { витку }\end{array}$ & 16 & \\
\hline
\end{tabular}

до шкільного навантаження.

Поряд із визначенням адаптаційних можливостей організму дитини важливою є оцінка фізичного здоров'я. Запропонований останніми роками термін «фізичне здоров'я» визначається як динамічний стан організму людини, який характеризується резервом функцій iii організму для виконання власних біологічних і соціальних функцій $[8,9]$. Наразі багатьма дослідниками зафіксовано погіршення фізичного здоров'я школярів, яке пов'язано з недостатньою руховою активністю, а тому низьким рівнем фізичної підготовки та адаптації до фізичних навантажень [10]. В табл.3 наведені дані, щодо показників Індексу Руф'є, що отримані при обстеженні дітей гімназії.

\section{Дані 3 вивчення стану функціонального резерву серцево-судинної системи школярів гімназії методом Руф'є}

\begin{tabular}{|l|c|c|}
\hline \multicolumn{1}{|c|}{ Оцінка стану } & Всього дітей $\mathrm{n=75}$ & Всього дітей \% \\
\hline Високий & 1 & 1.3 \\
\hline Вище середнього & 7 & 9.3 \\
\hline Середній & 16 & 21.4 \\
\hline Нижче середнього & 30 & 40 \\
\hline Низький & 21 & 28 \\
\hline
\end{tabular}

Наші дослідження виявили низький рівень адаптації дітей середнього шкільного віку до фізичного навантаження: у 68,0\% дітей показники резерву серцево-судинної системи були нижче середнього, у $21,4 \%$ учнів вони були середніми і тільки $10,6 \%$ школярів-гімназистів мають високий і вищий за середній рівні фізичного здоров'я. Згідно з наказом MO3 №518/674 (додаток 1) основну групу з фізкультури у школі можуть відвідувати учні, що мають високий і вищий за середній рівень фізичного здоров'я; у нашому дослідженні - це лише 10,6\% дітей. Школярі 3 середніми показниками $(21,4 \%)$ повинні займатися у підготовчій групі з фізкультури, діти 3 показниками нижче середнього та низькими $(68,0 \%)$ - у спеціальній групі з фізичної культури. Тобто, стан функціонального резерву серцево-судинної системи у більш, ніж половини дітей дуже незадовільний і відповідає навантаженням лише спеціальної групи.

Отримані нами дані мають ті ж самі тенденції що були отримані дослідженнями, проведеними у Національному університеті фізичного виховання і спорту України; за їх даними 89,1\% школярів мають низький та нижчий за середній рівні фізичного здоров'я. За даними Казак Л.М. та ін. авторів $[11,12]$ тільки у $1,6-7,5 \%$ дітей м. Києва зафіксовано високий рівень фізичного здоров'я, у 7\% вищий за середній, а у 65$93 \%$ - нижчий за середній і низький.

\section{Висновки:}

1. Наявність системної патології (найчастіше зустрічались захворювання кістково-м'язової системи у 97,2\% дітей), функціональні порушення з боку шлунково-кишкового тракту та серцево-судинної системи, (є проявами змін у вегетативному гомеостазі у 46,7\% випадків), свідчать про порушення адаптаційних можливостей дітей гімназії середнього шкільного віку до психоемоційних перевантажень на тлі низьких функціональних резервів серцево-судинної системи, які є наслідком недостатнього фізичного навантаження дітей та одночасним збільшенням об' єму учбового матеріалу.

2. У більшості учнів реєструється середній фізичний розвиток $(70,7 \%)$; інші учні гімназії мають фізичний розвиток вище середнього $(15,3 \%)$, високий та дуже високий $(1,6 \%)$; у 5,3\% школярів фізичний розвиток нижче середнього. У той же час функціональні можливості серцево-судинної системи за індексом Руф'є значно гірші: тільки 10,6\% школярів мають високий та вище середнього рівень фізичного здоров'я (можуть відвідувати основну фізкультурну групу), $21,4 \%$ учнів мають середній рівень (можуть відвідувати підготовчу групу), і більшість дітей - 68,0\% мають рівень фізичного здоров'я нижче середнього та низький (повинні займатися у спеціальній групі).

3. Для поліпшення рівня фізичного здоров'я дітей необхідно звертати увагу лікарів, педагогів і батьків 
на організацію здорового способу життя та проводити просвітницьку роботу щодо проведення систематичних індивідуалізованих оздоровлюючих заходів для дітей з відхиленнями у стані здоров’я. Отримані дані потребують перегляду шкільної програми, у тому числі з фізичної підготовки дітей гімназії.

\section{Література}

1. Стан фізичного здоров'я дітей шкільного віку та шляхи його підвищення / В.П. Неділько, Т.М. Камінська, С.А. Руденко // Перинатология и педиатрия. -2009 . - №2.- С.72-74.

2. Стан і перспективи ринку пріоритетного наукового напрямку „Охорона здоров’я дітей шкільного віку та підлітків” / Р.В. Богатирьова, С.М. Горбань, Н.Г. Гойда [та ін.] // Лікарьська справа.-2000.-№1.-С.3-6.

3. Бесєдіна О.А. Актуальні проблеми і основні напрямки розвитку профілактичної науки і практики / О.А. Бесєдіна, Т.М. Кошакова, Г.М. Даниленко.- Х.,1997.-С.51-55.

4. Квашніна Л.В. Нові підходи до оцінки стану здоров'я і діагностики ранніх його порушень у дітей шкільного віку: автореф. на здобуття наук. ступеня докт. мед.наук: спец. 14.00.09 «Педіатрія»/ Л.В. Квашніна.- К., 2000.-36 с.

5. Кухарська А.В. Особливості фізичного розвитку дітей молодшого шкільного віку з вегетативними дисфункціями / А.В. Кухарська // Педіатрія, акушерство та гінекологія. - №3. - 2009. - С.27-30.

6. Яцула М.С. Синдром шкільної дизадаптації: актуальність проблеми в першокласників // М.С. Яцула, С.Л. Няньковський // Педіатрія, акушерство та гінекологія. - 2008. - №1(425). - С.17-19.

7. Мойсеєнко Р.О. Здоров'я дітей шкільного віку та першочергові заходи з метою його поліпшення / Р.О. Мойсеєнко // Охорона здоров'я України. - 2002. - №3-4. - -P.7-11.

8. Апанасенко Г.Л. Оценка физического здоровья детей и подростков / Г.Л. Апанасенко // Мед. всесвіт. - 2004. -Т.4, №1. -С.94-106.

9. Апанасенко Г.Л. Эволюция биоэнергетики и здоровья человека / Апанасенко Г.Л. // Петрополис, 1992.-123c.

10. Моисеенко Р.А. Государственная политики относительно охраны здоровья матери и ребенка на этапе реформирования отрасли / Р.А. Моисеенко // Современная педиатрия. - 2005. - №2(7). - С.25-27.

11. Козак Л.М. Физическое развитие и состояние психофизиологических функций у детей младшего школьного возраста / Л.М. Козак, Л.Г. Корабейникова, Г.В. Корабейников // Физиология человека. $-2002 .-$ Т.28, №2. - С.35-43.

12. Пересыпкина Т.В. Школьная медицина - проблемы и возможности / Т.В. Пересыпкина // 3 турботою про дитину. -2012 . - №7(34). -С.4-7.

13. Поташнюк И.В. Состояние здоровья учащихся гимназии на завершающем этапе образования и пути его улучшения / И.В. Поташнюк, И.П. Козярин // Современная педиатрия. -2004 . -№3(4). - С.16-19.

\section{СОСТОЯНИЕ ЗДОРОВЬЯ ДЕТЕЙ СРЕДНЕГО ШКОЛЬНОГО ВОЗРАСТА ОДНОЙ ИЗ ГИМНАЗИЙ Г. КИЕВА}

\author{
А.В. Тяжкая, Л.Н. Казакова, \\ М.М. Васюкова, А.М. Антошкина
}

\author{
Национальный медицинский университет \\ им. О.О.Богомольца \\ (г.Киев, Украина)
}

Резюме. В связи с развитием сети гимназий в г. Киеве, повышением психоэмоциональной нагрузки у учеников специализированных школ нами было изучено состояние здоровья, показатели физического развития и адаптационных возможностей сердечно-сосудистой системы у 107 детей 5-6 классов одной из гимназий в г. Киеве. Установлено, что в структуре заболеваемости у 97,2\% детей преобладали изменения костномышечной системы (преимущественно сочетание патологии): сколиоз и нарушения осанки - у $33,6 \%$ и $36,4 \%$ соответственно; плоскостопие - у 49\%, деформация грудной клетки и остаточные явления рахита - у 24,5\%, патология свода стопы - у 49\%, нарушения прикусу, кариес зубов - у 11,5\% детей. Заболевания желудочно-кишечного тракта, преимущественно функционального характера, имели $41,1 \%$ детей. Патология ЛОР-органов и патология зрения отмечены у $33,7 \%$ и $24,0 \%$, соответственно. При оценке физического развития установлено, что 70,7\% учеников гимназии имеют средний, 13,3\% - выше среднего, высокий и очень высокий уровень физического развития; при этом дисгармоничное развитие выявлено у $21,3 \%$ детей, у половины детей из них - за счет ожирения 1 степени.

Для разработки индивидуальных рекомендаций к физическим нагрузкам оценивали адаптационные возможности сердечно-сосудистой системы по индексу Руфье. Только 10,6\% школьников-гимназистов имели высокий и выше среднего уровни физического здоровья; у 21,4\% учеников показатели были средними (возможность посещать подготовительную группу). У большинства же $(68,0 \%)$ детей зарегистрирован функциональный резерв сердечно-сосудистой системы ниже среднего, т.е. согласно приказу М3 Украины №518/674 они могут посещать только специальную группу по физкультуре. Результаты наших исследований свидетельствуют о низком уровне адаптационных возможностей сердечно-сосудистой системы, наличии сочетанной системной патологии на фоне относительно удовлетворительных показателей физического развития, что требует разработки индивидуализированных реабилитационных и тренировочных программ ученикам гимназий для повышения их возможностей по выполнению учебной нагрузки.

Ключевые слова: ученики гимназии, показатели здоровья, физическое развитие, индекс Руфье.

\section{THE HELTH CONDITION OF MIDDLE SCHOOL AGE CHILDREN EXAMINED IN ONE OF GYMNASIUM IN KYIV}

\author{
A.V. Tjazhkaja, L.N. Kazakova, \\ M.M. Vasjukova, A.N. Antoshkina
}

\section{A. Bogomolets National medical university (Kyiv, Ukraine)}

Summary. Since the development of a network of gymnasium schools and an increase of psycho-emotional load of students of specialized schools, we studied the health status, physical development, and adaptive capacities of the cardiovascular system in 107 children grades 5-6 of one of the gymnasium schools in Kyiv. It was found that the structure of morbidity in $97.2 \%$ of children prevailed changes of the musculoskeletal system (mainly a combination): scoliosis and incorrect posture - at $33.6 \%$ and $36.4 \%$, respectively; flat feet - 49\%, chest deformity and residual effects of rickets - at $24.5 \%$, the pathology of the foot arch - $49 \%$, malocclusion, dental caries - in $11.5 \%$ of children. Gastrointestinal disease, predominantly of a functional nature, was observed in $41.1 \%$ of children. Pathology of upper respiratory tract and pathology of vision were observed in $33.7 \%$ and $24.0 \%$, respectively.In assessing the physical development it was found out that $70.7 \%$ of gymnasium school students have an average level of physical development, while $13.3 \%$ - have higher than the average, high, or very high level of physical development; disharmonious development was detected in $21.3 \%$ of children, half of them children with 1 degree of obesity. For the development of individual recommendations as to physical activities, the adaptive capacity of the cardiovascular system was assessed by the Ruffier index. Only $10.6 \%$ of students had high or above average levels of physical health; $21.4 \%$ of students had average levels (able to attend a preparatory group). The majority $(68.0 \%)$ of children registered functional reserve of the cardiovascular system as below average, i.e. according to the order of the Ministry of Health of Ukraine №518/674, they may only attend a specialized Physical Education group. Our results indicate a low level of adaptive capabilities of the cardiovascular system, the presence of combined systemic disease on the background of relatively satisfactory parameters of physical development. This requires the development of individualized rehabilitation and training programs of gymnasium school students in order to enhance their ability to meet the academic load.

Keywords: school students, health indicators, physical indices, Ruffier index. 